\title{
Principles before Profits: An Interview with S. Truett Cathy
}

\author{
Miles Davis, Ph.D.
}

Leyland M. Lucas, Ph.D.

$\boldsymbol{R}$ ecent attention bas been given to organizations that claim to run on faith-based principles. Activities such as at work bible study groups, charitable giving, and the individual practices of the owners are often the focus of such discussions. In such discussions little attention has been paid to those who not only bold strong religious views, but have chosen to put those views into practice-even when it may not appear to make good business sense.

Since 1946, S. Truett Cathy, founder and chairman of Chick-fil-A Inc., has run bis enterprises based on bis understanding of Christian principles. Starting with bis first restaurant, the "Dwarf Grill," which be opened with bis brotber Ben in 1946, continuing when be opened the first "Chick-fil-A" in 1967, and even as be finished the remodeling of the companies beadquarters in 1997, S. Truett says be tries "to glorify God by being a faithful steward of all that is entrusted to us and to have a positive influence on other people...." In fact, this purpose is engraved in a bronze plaque that rests at the entrance to Chick-fil-A's corporate beadquarters in Atlanta, Georgia.

In practice, this purpose has lead S. Truett to never bave bis businesses open on Sunday, a time in the quick service industry that normally generates 20 percent of revenue. It has caused him to shut down another restaurant venture, Markos in Florida, rather than serve alcobol, which most patrons wanted. Despite bis staunch adberent to principles that seem to run counter to "good business sense," S. Truett Cathy has built a successful, privately beld organization that operates in 38 states, has more than 1,300 franchisees, and generates over $\$ 2$ billion a year in revenue.

In the following interview, S. Truett offers bis perspective on why focusing on principles is more important than focusing on profits and what be thinks it takes to succeed in business and in life.

NEJE: Mr. Catby, unfortunately we're starting the tape after you just explained to us your past. But the first question that people always ask and I'm curious about is, "How did you do it?" What would you say are the fundamental elements of your success?

S. Truett Cathy: I'm writing a book right now, How'd You Do It, Truett?

NEJE: Well, give us a preview of the book?

S. Truett Cathy: All right, number one is you got to want to.
If you don't have that, nothing else is going to work. Not I'm trying to want to. I'd like to be good golfer. . I'd like to be a concert pianist. I grew up in the Great Depression, you never experienced that, few people have. But I've lived in times of poverty; I've lived in times of plenty. We might have experienced times of plenty, but especially we learned from poverty. We struggled to have a place to live, as well as food for our table, and I never had anything that I really haven't had to work for. It wasn't just given to me. What little bit of money I had, I had to share with my family. Starting off at age eight, going in a restaurant, we started buying Cokes, six for a quarter, do you remember that? You could buy Cokes six for a quarter.

\section{NEJE: No, I'm not quite that old.}

S. Truett Cathy: Well few people do. But that was the beginning, I realized then I could make six cents a bottle. So for a quarter I would buy those [sodas] and turn around in the neighborhood and make five cents on the turnaround. Then we went back and got more and more and more, and then finally had the resources and went to the Coke truck and bought 24 Cokes for eighty cents. We'd sell those 24 Cokes for five cents a piece, get the eighty cents we spent, plus forty cents. So that's, to me, a big difference back then. The first thing I did as a result was to buy a bicycle. I paid $\$ 4$ for it. It didn't have any fenders, but it had round wheels and a big frame. I had never bought anything in my life that I appreciated more than that bicycle because I had to buy it and had to earn it to get it-it wasn't going to be a gift.

So those are some experiences I've learned from. And I went from that to selling magazines. Then I had a paper route that I carried for seven straight years. During that time that I learned the importance of taking care of the customers. You put the paper behind the screen door, keep the dog from chewing it up, [and] put it up on the rocking chair.At that period we had an evening newspaper competition and I was always challenged by being the winner of the pocket knife, a tee shirt, or maybe a trip to Jacksonville Beach. I was challenged by that, I always achieved certain goals that I had set for myself to be a winner. I never got excited about school, but I got excited about working. I was drafted into the Army right after I finished high school, so I didn't get to go to college but that never bothered me. I never liked school anyway. I am glad to work and I do today.You couldn't work and be this old unless you're doing your very best. It's when we do less than what we could do, or are expected to do [that causes problems]. 
Oftentimes I say there are three pieces to success, and this works for everybody, under all circumstances. Number one is you got to want to. If you don't have that, nothing else is going to work. Number two, you got to develop the skills and the know-how. And three, you got to do it. Many people have a lot more talent than they exercise. They go to school and learn all these things, and blow it when they get out there and they're not willing to pay the price that they need to pay. It takes a lot of "want-to" in life-a lot of "want-to." You got to really want to. I had to be able to do whatever it took to achieve the goal that I'd set for myself.After getting out of the service, my brother and I pulled our resources and came up with \$4,000. A loan company said if I'd sell an automobile I had, I'd get a loan for $\$ 6,600$, so at that time back in 1946 , we went to buying part of the of "Dwarf Grill" and the lot next to it. The lot was about 50 by 150 [feet], and was right near a Ford plant. We invested a total of $\$ 10,600$ - first into the property then into building a building. That's the kind of debt that we're committed to and it was a strong commitment. I was single so I got my room right next door to the restaurant. I was available 24 hours a day, six days a week. I was totally committed and that makes the difference in business life, as well as home life, and your relationship to the Lord. In commitment, you see strange and unusual things happen when you're truly committed to something.

NEJE: How would you look at the issue of talent verses luck in the story of Chick-fil-A?

S. Truett Cathy: Well, there's no such thing as luck. People say it's luck, and I say the harder you work the luckier you get. It will always be the harder you work the more successful you will be. But being brought up in a boarding house where my mom's bread was limited to feed the family, they had seven rooms in the rented house and two meals a day. And at an early age I learned how to shuck corn and scale fish, wash dirty dishes, set the table, and go shopping for my mom. That was a learning experience for me. Coming from that background, I guess food would probably fit in. There was a competence that I learned in the boarding house days. And I like to eat as well. I used to have a hobby of baking cakes on Sunday afternoon. Mom would let me take a recipe and go to the store if I'd clean up afterwards.

God designed that we would want to be somebody and see something through in our lifetime. It never comes natural, that's for sure. Character is not a burden, but we blow it. You see people a lot of times that have a lot, a lot of potential and blow it simply by making the wrong decision. If you make a good decision, if you make it wrong or not, this might be the thing that results. But you see that today. It doesn't come overnight, it doesn't come easy but it will happen. And you can accomplish anything if you really want to.
If you don't have that much, I agree it's just not going to happen and I guess I feel like I never planned Chick-fil-A, it just came about. I say, take advantage of unexpected opportunities and you don't recognize them sometimes until it's too late. You look back and you wish you'd done this or done that, but you just go through life one time, you don't have a chance to go back and redo it.

There's no shortcut to success. It's true you're due to gain through the errors that you make. The shortcut is to observe what's worked in life through times and try to imitate it. Don't think you have to be around the drugs, alcohol, and sex just to see what it's like because you can look at relatives, and see what they've done, mistakes they've made. I got a good lesson in my Sunday school lesson about life. I was always taught that the truth is in the Ten Commandments. I mean, people have trouble with lying. It's like even our [past] president, Bill Clinton, he did a bad thing but the worst of it is he lied, under oath, about what took place. You can't lie and lie, it's a sin with God. Another chief executive officer of the largest company of the world, Lockheed, lied about things. The president and CEO of RadioShack, who was doing a good job for the last five years, was dismissed because he lied on his application. On his application he put down degrees he earned in college, but he never attended college. So still I believe firmly in the Ten Commandments; they're important to us and we need to give attention to that.

NEJE: How does our changing world impact today's entrepreneur, especially in a quick service restaurant? And what I mean by that is do demographic shifts in the United States-such as the aging population or a more diverse population-mean that your stores will at one point say, “Eat More Tacos?” Or do geographic shifts, that the world is getting smaller, mean that maybe you'll go international to sustain the great growth of Chick-fil-A?

S. Truett Cathy: We went to 37 states, and we made the mistake of going to South Africa and building three places there. It was at five years and hadn't made any money; it cost us to keep the doors open. We had the opportunity to renew our leases from those five years or pull out.And so we pulled out. Our area's right here in the United States and our neighboring states in the union. It's tiny but our goal is to expand in areas that we already recognize, rather than going into unknown territories.

NEJE: Please explain why you say that it was a mistake going to South Africa.

S. Truett Cathy: It's the fact that we were losing money. We couldn't get the merchandise and paper goods there properly labeled. People there were used to having Coke with maybe one piece of ice, if they wanted ice. We fill the cup up with a 
half a cup of ice, and they told us they were getting gypped. Because they were the customer, you put fresh ice in it. We told them iced tea and Coke taste better with ice. We had to prove our point; we had to educate the people. The economy wasn't bad, and there was no competition to speak of. But nevertheless, we had a bunch of great employees. They were all excited, but nonetheless, it just wasn't practical.

\section{NEJE: What business would you start today, given our changing world? Would you do Chick-fil-A all over again?}

S. Truett Cathy: Sure I would. I think it was God's gift to have that. I always thought about having a chain of restaurants until I had two, but I realized then that I had one too many. If I just have one I can do a better job. I was trying to go back and forth to operating two restaurants, so it was a big issue for a long time, running something else and Chick-fil-A. You can tell me and explain that we started off as something not much, the difference is our concept. In the beginning shopping malls would not talk to you about fast food. They didn't want the smoke fumes tainting things inside. So we had the shopping mall concept. It was a new concept; Chickfil-A itself was brand new. We introduced and educated people about our boneless chicken breast sandwich.

\section{NEJE: Did you create the idea of a quick service store in a mall?}

S. Truett Cathy: I created that.And I saw that we did a lot of things different. We're actually closed on Sundays, we're neat. I've been doing it for 60 years and it's never changed. It's the most important decision I've made.A man asked me, "How do you figure that because 20 percent of sales are generated on Sunday in fast food?" I replied, "Well, number one it honors God. And secondly, it also attracts the kind of people who appreciate a Sunday off."We weren't so sure if it worked or if not, but we had that opportunity and family is very important.America has a great quality of home life as well as a faith in the Lord. And so we offer this and that's the reason we employ 500 people and we only have a 3.5 percent turnover. And personally, that's unheard of in anything, particularly in the food business.

\section{NEJE: Why do you think that your turnover is so low? What is it that you're doing?}

S. Truett Cathy: Giving people Sunday off is just one of the factors. We employ a lot of mothers. We give them Saturday and Sunday off, we think of the family. We got high school and college people working on Saturdays, so we got the housewives who work all week and get off on Saturday and Sunday which is a great offer to them. They'll stay with you. The environment we offer them is inviting. We try to go with the scriptures and treat them like we want to be treated. Of course, it would be nice for them to give me the time off, when you work 24 hours a day for six days you're ready for a break. And you find that equipment needs to be rested a little while too. So it's worked out to our advantage that we're closed on Sundays.

NEJE: You're well known for your emphasis on character and principles based on biblical teachings in running a business. Do you think that baving that sense of character and principles presents unique challenges in the business world?

S. Truett Cathy: You have to have principles. It should change the world of business. But business people are more interested in the bottom line than we are in people. We're a private company, so we're more concerned about the people. The bottom line takes care of itself. But more people see what that bottom line looks like. Earnings generate more profit. So we have a special privilege where we use our resources to do some very unusual things.

NEJE: Mr. Catby, do you think it's barder to maintain those principles in 2006 than in 1946, when you started your business?

S. Truett Cathy: I don't. You just have to make up your mind as to whom you're going to try to please. Shopping malls are normally open on Sunday and there are a few instances in which we were denied to go in there because of the fact we're closed on Sunday. You don't earn much money like that. We feel like people appreciate you living up to what you trust to be. I teach Sunday school to 13-year-old boys. I asked them one time, "How would you feel if I was to open my cash register today on Sunday while trying to be a success. One little boy said, "You would be a hypocrite." When I went to school, it was required in public school to bring a Bible verse to school on Monday morning. From those, they would give you one Bible verse for the week. When I was in third grade, my Bible verse was inspected, my name was up on the board and Proverb 22:1 was written out: "Well the good name would rather be chosen than great riches." I asked my 13-year-old boys, "How many of you would like to have a million dollars?" All the hands went up. Mom is getting new dresses; Daddy could have a new pick up trucks and shot gun shells; you're getting a go-cart and mini-bike.' And I said, "Let me tell you something better than that ... the good name, with a good reputation." And my little boy said, "Well suppose you got a good name." And I said, "No, you have to reearn it everyday. It's nothing you can buy; it's something you have to earn. The way I figure it, and I find this very true, I don't know how much of that caused me to try to maintain a good name. But in the food business you have to remember to do things right all the time, not just sometimes. Because if you get disappointed one time, that's 
the end of that 25 times. If you get disappointing quality of food or are mistreated by an employee, you're likely to never go back again. And certainly not go around cheerleading for Chick-fil-A after that experience, ever. So we have to things to make it right every time.

NEJE: How do you convey those core values of your faith to your management team?

S. Truett Cathy: We have an annual seminar that lasts four days and the last few have had more than 3,000 people. We provide outstanding speakers, motivators. We also try to help them in their home life because I can't expect a person to do their best in business when they've got problems at home. One reporter wrote an article on us offering counseling services to families. That opened up a whole group of newscasters on radio and TV wanting to know more about us.That's unusual for a company that cares for its people and their homes. And they said, "Why did you do it?" I said you can't expect a person to run a business who's got severe problems at home; it's just not going to happen. It is important that you try to maintain a stable home life, as well as stability in your business. Make it a place you want to stay. We have very few leaving the group for reasons that are uncontrollable.

NEJE: You often bear talk now of what is called "corporate social responsibility." There are some who emphasize that it's the shareholders and those who say it's the stakeholders and I just wonder, what are your views on corporate social responsibility?

S. Truett Cathy: You should be honest to your stockholders. Look at it the way they practice in the Navy where the captain's always the last one to depart from the ship. If you got a sinking ship, it is the captain who leaves last. I felt that in business it's the same way, you got to be responsible to the stockholders-unlike a business owner I heard about. He took his money and left the company in bad shape. He shouldn't have walked off, leaving his business in trouble. He did all he could to leave the scene. You should take care of the stockholders, those who invest their life savings in it and trust in the company. They shouldn't be disappointed by the person they're trusting in, with mistake and no protection really, but that's the stock market. But it gets back to biblical principles. Treat others like you like to be treated, be honest and be truthful. These are the basic things that are expected of an individual.

NEJE: I also know from your book Eat Mor Chikin: Inspire More People that one of your principles is to be a good steward.

S. Truett Cathy: Right. It's very true. I think all we have is promised to God anyway. All we have is a gift from God. We practice tithing and other things like being a good neighbor and treating others like we'd like to be treated. Chick-fil-A has been leading too and there are a lot of things we do besides cooking chicken. We have just awarded $\$ 20,000$ to young persons who work for us. If they have been working for us for 2 years and work 20 hours a week, we give then a $\$ 1,000$ scholarship. We've awarded $\$ 20,000$ every year, which have totaled $\$ 20,000,000$. And it adds up. We build foster homes. We have 12 foster homes, and we have a scholarship program for employees. We've taken over what was previously a private boarding school for eighth to twelfth graders. The school was closed. We looked into it and we were amazed that the 28-acre land, started back in 1902 by Martha Berry, got the support of great people like Henry Ford, Emily Vanderbilt, and Franklin Roosevelt. The facility supplied the resources that allowed us to rebuild the campus. We recently took over a dairy farm there, converted it into a family enrichment program for families who need a shot in the arm. We encourage them to stay together. We are running a Pro-Dad's Day in Tampa, Florida. We're going nationwide with it, and urging fathers to spend the day with their son. We are encouraging them to come to Chick-fil-A to eat and sit and talk with each other. The dad plays into the stability of the homes and spending time with the children. Many times children don't hear from the fathers unless they're scolding them about something.Just talk to them, talk to them about anything they want to talk about. But don't just talk to them when you are scolding them and getting after them. Find times when you can encourage them. That makes all the difference.

NEJE: I have three last questions. One, in retrospect, what do you consider your greatest contribution to the organization and to entrepreneurship?

S. Truett Cathy: Well my family is very important to me. I have 3 dedicated children, dedicated to the Lord, but on top of that they have a giving spirit. I'm very excited how they treat Chick-fil-A. I have 12 grandchildren. I was just awarded the first, second, and third generation down in Saint Petersburg. I feel like I've been thrown some wealth, but I've got money that I can use for myself. But also I've got some other business investments that I use to help be successful in these certain situations. I see young people grow up and they're high school and college students now working on the staffs who are career persons. And we have, as I mentioned, 65 percent of operators [franchise owners] out there who grew up in Chick-fil-A. We raised them. For some of them it's the only job they've had. And 15 boys I had in my Sunday school class over a period of years made a career at Chick-filA. There's nothing wrong with working hard as young people.You have to work. And if you like to work, there's nothing wrong with liking to work. So it's been satisfying to me to have so many young people that want to choose a career in Chick-fil-A. And the quality of people who we have here on 


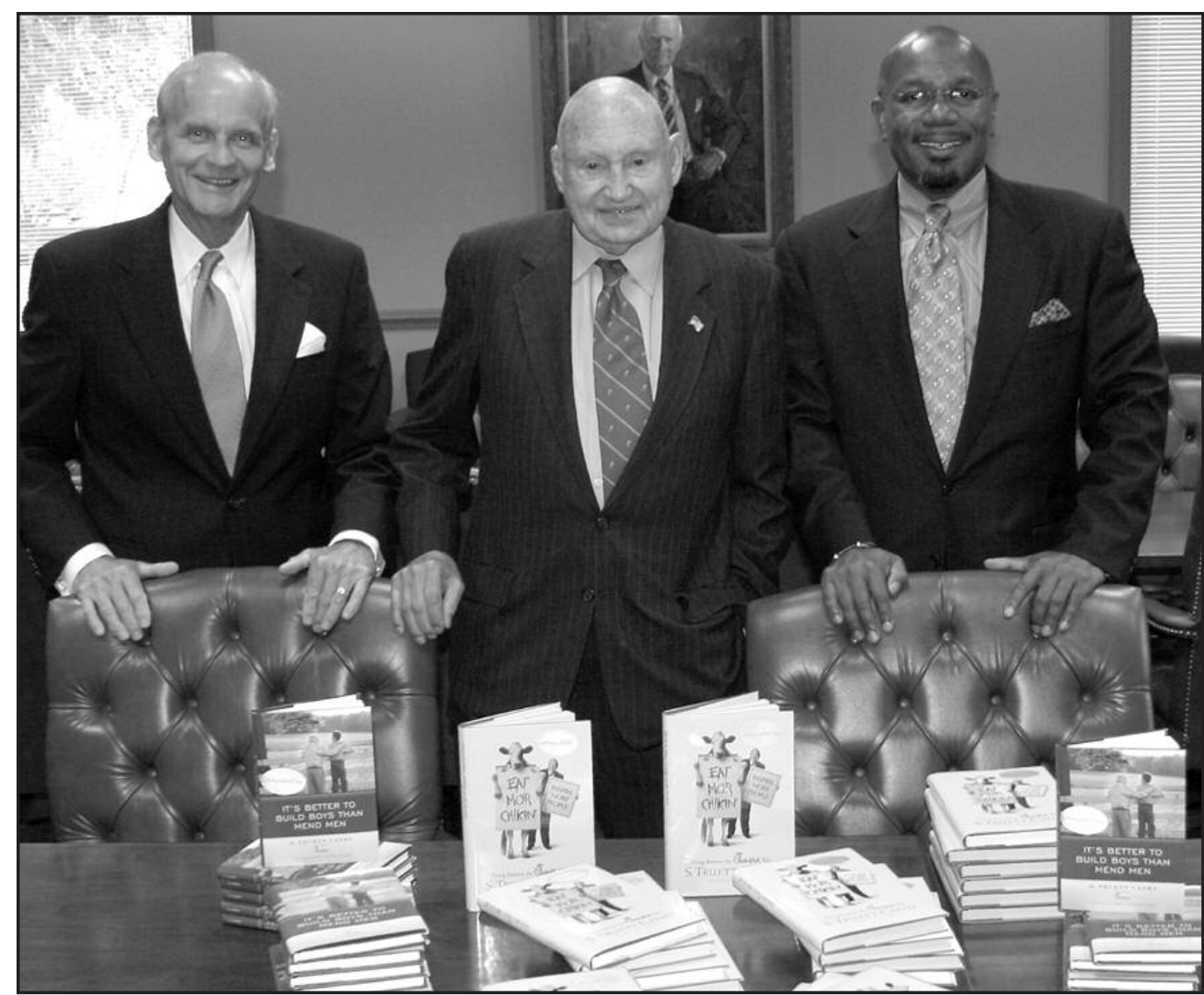

S. Truett Cathy (center), founder and CEO of Chick-fil-A, recently shared some of his inspirational writings on a giving spirit with Dr. Randy Boxx (left), dean of the Harry F. Byrd Jr. School of Business at Shenandoah University, and Miles Davis, associate professor of management and director of the Institute of Entrepreneurship in the Harry F. Byrd Jr. School of Business.

our staff makes my job much easier. It's a pleasure to come to work with the atmosphere that's created here. So I feel Chick-fil-A brings good. I think we honor God in the things we're trying to do.

\section{NEJE: When you retire from Chick-fil-A, what would you like to say is your greatest legacy to the organiza- tion?}

S. Truett Cathy: I think the greatest contribution would be the fact that we're closed on Sunday. We've done that for 60 years. And there are times when you mention Chick-fil-A, yeah, that's the place that's closed on Sundays.And it gives us opportunity to explain well sure, you can't go eat at Chick-filA because they're closed on Sunday to respect the Lord's Day. 'Honor the Lord's Day and keep it holy. It's a special day that the Lord has given Man. We need that day off, it's to honor God. We just need a day off to think about the little things that are important. And that's the bottom line.

\section{NEJE: My last question, when people bear the name of} your organization, what do you want them to think of?

S. Truett Cathy: I think it would be of a quality operation where you have people who care about them and who practice going that second mile for the customer. That's where you get people who are totally dedicated to Chick-fil-A. They're your cheerleaders, it's that kind of advertisement that you sell by. The general public is more important than adver- tising over the TV or radio, we have don't have the advertising budget. We're the largest company I have seen without advertising on TV or radio, but I think we have the loyalty of the employees and we have loyal customers. They're our cheerleaders out there telling people about the great experience they had a Chick-fil-A.

We have maintained a good reputation as far as service. Occasionally someone has gotten disappointed but we do everything we possibly can to correct the situation. I'll send a letter of apology along with a book; the operation will sometimes send flowers to that customer or some other things. We ran into a situation in the Carolina's where a lady had driven 200 miles and she had another 200 miles to go. She got to Chick-fil-A and realized she had left her pocketbook. Of course we didn't charge her anything for food, but she didn't have gas money to get back to where she came from and the operators were aware of that. The employees collected \$23-\$1 a piece-and gave it to the lady. It was an unusual thing that we can do that other people will not do. They could do, but won't. It's a business of serving people.

Editor's Note: The growing area of spirituality research and theory in the study of management often presents opinions and references that are not commonly shared by all members of the academy. The New England Journal of Entrepreneurship does not endorse nor does it disavow the views of contributors to the Journal. 


\section{About the Authors}

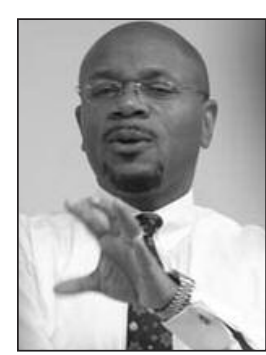

Miles K. Davis (mdavi3@su.edu) is an associate professor of management at Shenandoah University and is director of the Institute for Entrepreneurship at the Harry F. Byrd, Jr. School of Business. He teaches courses on entrepreneurship, organizational behavior, and management, and the capstone business and strategy courses in the undergraduate and graduate program. Dr. Davis' research interests include managing planned change in organizations; leadership; entrepreneurship; and, ethic, moral, and spiritual issues in organizations. He has had refereed journal articles published in each of these areas and is associate editor of the New England Journal of Entrepreneurship.

Before becoming a university professor, Dr. Davis was a principal with EDS' E.Solutions Consulting organization, where he was responsible for worldwide delivery of organization transformation, business process reengineering (BPR), strategic planning and management, and change management consulting services to major corporations and government agencies. Dr. Davis continues to consult to companies worldwide, with a particular emphasizes on small and family-owned businesses.

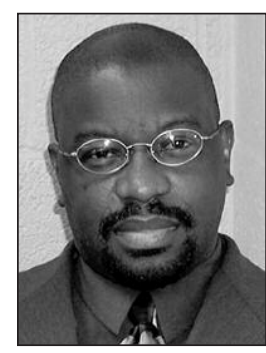

LEYLAND M. LuCAS (llucas@moac.morgan.edu) is an associate professor of management in the Earl Graves School of Business \& Management at Morgan State University. He received his Ph.D. in organization management from Rutgers University. Dr. Lucas has published papers in Entrepreneurship Theory \& Practice, International Journal of Technology Management, Journal of Knowledge Management, The Learning Organization, and Journal of Applied Management \& Entrepreneurship. His research interests include organizational search, knowledge management, opportunity recognition, minority and women-based entrepreneurship, and innercity entrepreneurship. 